\title{
Editorial: The Role of the Paleo-Critical Zone in Shaping Quaternary Hominin Evolution
}

\author{
Gary E. Stinchcomb ${ }^{1,2 *}$ and Emily J. Beverly ${ }^{3}$ \\ ${ }^{1}$ Watershed Studies Institute, Murray State University, Murray, KY, United States, ${ }^{2}$ Department of Earth and Environmental \\ Sciences, Murray State University, Murray, KY, United States, ${ }^{3}$ Department of Earth and Atmospheric Sciences, University of \\ Houston, Houston, TX, United States
}

Keywords: Critical Zone, paleoenvironment and paleoclimate, paleosol, paleo-Critical Zone, paleoecology

\section{Editorial on the Research Topic}

The Role of the Paleo-Critical Zone in Shaping Quaternary Hominin Evolution

\section{OPEN ACCESS}

Edited and reviewed by: Steven L. Forman,

Baylor University, United States

${ }^{*}$ Correspondence:

Gary E. Stinchcomb

gstinchcomb@murraystate.edu

Specialty section:

This article was submitted to Quaternary Science, Geomorphology and Paleoenvironment, a section of the journal Frontiers in Earth Science

Received: 22 March 2019 Accepted: 15 April 2019 Published: 01 May 2019

Citation:

Stinchcomb GE and Beverly EJ (2019) Editorial: The Role of the Paleo-Critical Zone in Shaping Quaternary Hominin Evolution. Front. Earth Sci. 7:95 doi: 10.3389/feart.2019.00095
This research topic examines the role(s) the paleo-Critical Zone (paleo-CZ) has played in shaping hominin evolution during the past 2.6 million years, extending from earliest evidence of hominins to the recently proposed Anthropocene. The $\mathrm{CZ}$ is defined as the zone that extends from the top of the canopy to the groundwater table and is where most life occurs (Brantley et al., 2007). Present-day CZ studies are cross-disciplinary and bring together sub-disciplines from geology, ecology, chemistry, engineering, and agronomy. Past evidence of the $\mathrm{CZ}$ is recorded across the globe in the (pre-) Quaternary stratigraphic record as paleo-CZs, archiving information pertaining to the past atmosphere, hydrosphere, lithosphere, pedosphere, biosphere, and anthrosphere (Nordt and Driese, 2013; Beverly et al., 2018; Lukens et al.). Thus, unlike more specialized paleoenvironmental research focusing on specific aspects of the Earth system (e.g., paleoclimate, paleovegetation), the paleo- $\mathrm{CZ}$ is a holistic approach that often requires collaboration amongst specialists who can straddle the bounds of a discipline. The expectation is that this holistic, cross-disciplinary CZ research will yield new insights into a zone that is critical for human survival.

The cross-disciplinary efforts of $\mathrm{CZ}$ research are discussed in the opinion piece by Ferraro et al., where they advance the notion that both modern- and paleo-CZ research endeavors should include archeology for several reasons. Importantly, Ferraro et al. note that in both modern- and paleo-CZs there is evidence of past human activity recorded in the archeological record. Thus, components of the CZ, e.g., pedosphere, biosphere, interact and have interacted in the past, with the archeological system. It is this archeological system that needs further integration with both modern- and paleo-CZ science. The opinion of Ferraro et al. is demonstrated in recent efforts to quantify the archeological record using an artifact mass flux variable (Stinchcomb, 2018) and in all articles included in the research topic presented here (Beverly et al.; Lukens et al.; Ruiz et al.; Santoro et al.).

Critical Zones in volcanic regions are a source of nutrient-soil that has benefited prehistoric and modern people. Ruiz et al. examined hominin and paleo-CZ interactions in volcanic settings and used historical accounts, archeology, geomorphology and land-use analysis to understand why past settlements were built near Costa Rican volcanoes. In one example, the pre-Hispanic peoples in the northern Poás region used the local geomorphology to serve as natural protection against pre-Hispanic volcanic activity. Our understanding of more advanced pre-Hispanic societies in Costa Rica shows that they also had a knowledge of hazard prevention and mitigation as indicated through slight changes in site placement after volcanic activity lessened (Ruiz et al.). 
Beverly et al. and Lukens et al. use pedosphere information archived in fossil soils (paleosols) to reconstruct paleo-CZ conditions associated with hominins and their early Miocene primate precursors. Late Pleistocene terrestrial deposits along Lake Victoria are one such setting containing paleosols that document precipitation deficit, 54 and $72 \%$ of modern precipitation (Beverly et al.). These paleo-hydrosphere data suggest that Lake Victoria was smaller than modern, which would have facilitated faunal and hominin dispersal across the equator and between rift basins (Beverly et al.).

Further back in time, an early Miocene outcrop near Karungu, Western Kenya, reveals a landscape-scale paleo-CZ that stands in contrast to a reconstructed paleo-CZ from nearby Rusinga Island (Lukens et al.). Using a suite of field and analytical techniques comparable with modern-day CZ studies, Lukens et al. showed that there was notable change in the biosphere component of the $\mathrm{CZ}$, ranging from open- to closed-canopy ecosystems between Kurungu and Rusinga. The lack of primate remains at the more open-canopy Karungu site is consistent with current knowledge of early Miocene primates favoring closed-canopy vegetation.

Food procurement almost always involves indirect or direct manipulation of the $\mathrm{CZ}$ through farming or pastoralism. However, some coastal-dwelling prehistoric groups, like those from the Quebrada Chaca canyon along the Pacific coast of the Atacama Desert, relied heavily on food consumption of marine resources (such as C. concholepas-loco) over the course of 9,000 years of prehistory (Santoro et al.). By quantifying the gross weight per shellfish species (biomass) from archeological sites

\section{REFERENCES}

Beverly, E. J., Lukens, W. E., and Stinchcomb, G. E. (2018). "Paleopedology as a tool for reconstructing paleoenvironments and paleoecology," in Methods in Paleoecology (Cham: Springer), 151-183.

Brantley, S. L., Goldhaber, M. B., and Ragnarsdottir, K. V. (2007). Crossing disciplines and scales to understand the Critical Zone. Elements 3, 307-314. doi: 10.2113 gselements.3.5.307

Nordt, L. C., and Driese, S. G. (2013). Application of the critical zone concept to the deep-time sedimentary record. Sediment. Record 11, 4-9. doi: $10.2110 /$ sedred.2013.3.4

Stinchcomb, G. E. (2018). Quantifying past hominin interactions with Earth's surface using the mass flux of along the Pacific coast cz, Santoro et al. found that despite El Niño Southern Oscillation-driven changes in marine productivity and demographic variability, the people's reliance on the local marine economy persisted. This one example shows cultural dietary resilience in the face of changes to the coastal paleo-CZ.

In summary, the works presented in this research topic show that the roles of the modern- and paleo-CZ in shaping primate and hominin evolution are complex, where many of these multifaceted relationships remain undiscovered. In some works, the presence of, and activities associated with, hominins and primates are partly controlled by the CZ (Beverly et al.; Lukens et al.). Whereas, in another example, the hominins in a coastal setting were resilient in their dietary needs, despite changes in their local CZ, demography and shifting marine sources (Santoro et al.). Although these works noted above highlight examples of hominin and primate interaction with the paleo-CZ, the interactions are clearly complex and suggest hidden variables remain undiscovered and could play a primary role in regulating interactions. Discovery of these variables and subsequent modeling efforts are major challenges that lie ahead and will require developing and adopting more versatile metrics, e.g., dimensionless numbers of weathering, human impact and ecological processes, that are widely applicable-creating a common language among modern- and paleo-CZ scientists.

\section{AUTHOR CONTRIBUTIONS}

All authors listed have made a substantial, direct and intellectual contribution to the work, and approved it for publication.

$$
\begin{aligned}
& \begin{array}{l}
\text { artifacts. } \\
8 / 0585
\end{array} \text { Geomorphol. } \quad 62, \quad 57-71 . \quad \text { doi: } 10.1127 / \mathrm{zfg} / 201 \\
&
\end{aligned}
$$

Conflict of Interest Statement: The authors declare that the research was conducted in the absence of any commercial or financial relationships that could be construed as a potential conflict of interest.

Copyright (C) 2019 Stinchcomb and Beverly. This is an open-access article distributed under the terms of the Creative Commons Attribution License (CC BY). The use, distribution or reproduction in other forums is permitted, provided the original author(s) and the copyright owner(s) are credited and that the original publication in this journal is cited, in accordance with accepted academic practice. No use, distribution or reproduction is permitted which does not comply with these terms. 